\title{
EL PASADO PREISLÁMICO EN AL-ANDALUS: RECEPCIÓN DE LA ANTIGÜEDAD Y LEGITIMACIÓN DEL PODER OMEYA (SS. VIII-X)1
}

Jorge Elices Ocón ${ }^{2}$

\begin{abstract}
Resumen
Tradicionalmente se ha considerado que las sociedades islámicas medievales no tuvieron ningún tipo de interés por conocer o preservar la antigüedad. Mi contribución señala la necesidad de reconsiderar este paradigma. Para ello analizo un caso particular, que fue el tema de mi tesis doctoral: la recepción de la antigüedad bajo dominio musulmán en la Península Ibérica o al-Andalus, durante los primeros siglos (VIII-X d. C).

Este artículo señala que al-Andalus constituye un escenario único para los estudios de recepción. Se pone de manifiesto la existencia de una profunda y novedosa reflexión sobre el pasado, que abarca varios aspectos. Por un lado, una llamativa reinterpretación de las estatuas clásicas, que pasan de ser consideradas ídolos paganos a ser vistas como imágenes talismánicas y protectoras de una ciudad o comunidad. Por otro lado, la apropiación y reelaboración del pasado por los cronistas árabes, con fines políticos y de legitimación.
\end{abstract}

\section{Palabras claves}

Al-Andalus; recepción; reutilización; estatuas; Califato de Córdoba; legitimación.

\section{Resumo}

Tradicionalmente se considerou que as sociedades islâmicas não tiveram nenhum tipo de interesse por conhecer ou preservar a Antiguidade. Minha contribuição assinala a necessidade de reconsiderar este paradigma. Para isso, analiso um caso particular, que foi o tema de minha tese de doutorado: a recepção da Antiguidade sob o domínio muçulmano na Península Ibérica ou

\footnotetext{
${ }^{1}$ Este artículo ha sido redactado a partir de un seminario con el mismo título impartido en el CSIC el 14 de Diciembre de 2017.

${ }^{2}$ Investigador Postdoctoral - Universidad Federal de São Paulo, São Paulo, Brasil. E-mail: jorge.elices.ocon@gmail.com
} 
al-Andalus, durante os primeiros séculos (VIII-X d.C.). Este artigo assinala que al-Andalus constitui um cenário único para os estudos de recepção. Revela a existência de uma profunda e inovadora reflexão sobre o passado, que abarca vários aspectos. Por um lado, uma interpretação impressionante das estátuas clássicas, que deixam de serem consideradas ídolos pagãos para serem vistas como talismãs e protetoras de uma cidade ou comunidade. Por outro lado, a apropriação e reelaboração do passado pelos cronistas árabes, com fins políticos e de legitimação.

\section{Palabras-chave}

Al-Andalus; recepção; reutilização; estátuas; Califado de Córdoba; legitimação.

Hace ahora ocho años llegué a Madrid para comenzar el Máster de Historia y Ciencia de la Antigüedad que todavía imparten, con mucho éxito, las universidades Complutense y Autónoma de Madrid. Entre las asignaturas a cursas se encuentra Legado de la Antigüedad, impartida por la Prof. Gloria Mora Rodríguez (Universidad Autónoma de Madrid). El tema me llamó la atención desde el primer momento y debo confesar que era muy poco lo que sabía hasta entonces sobre legado y recepción. Una de las cosas que más me sorprendieron fue comprobar como en los estudios sobre el tema no se centran en señalar lo que ocurre en el mundo islámico. Aunque las fronteras lo clásico no coinciden con las del Imperio Romano, ni siquiera con las de Alejandro Magno, el mundo islámico siempre ha sido excluido de esta perspectiva. El centro de atención siempre ha estado en la Europa cristiana y en la civilización occidental y el paradigma asumido es que las sociedades islámicas siempre han manifestado un rechazo y un desinterés por todo lo relacionado con la antigüedad.

A medida que me adentré en el tema fui descubriendo que esta perspectiva no responde a la realidad sino que parece ser una construcción interesada. Cada vez resulta más evidente que los procesos de recepción en la Edad Media son más importantes y anteriores en el mundo islámico que en Europa, sin embargo, por condicionantes ideológicos o religiosos o por barreras lingüísticas y académicas, nunca se han tenido en cuenta (Greenhalgh, 2009). Descubrí entonces que el origen de este paradigma, que se repite sin cuestionar su veracidad, se encuentra en las ideas esgrimidas por los viajeros y arqueólogos europeos de los siglos XVIII y XIX para justificar el saqueo y el pillaje de antigüedades y su traslado a los grandes museos y bibliotecas occidentales. En Europa las antigüedades están seguras. En Europa sí son valoradas y reconocidas (Gress, 1998; Tietze Larson, 1999/2000; Díaz-Andreu, 2007). Es la idea que expresaba Theodor Mommsen cuando se refería al Islam como "el destructor del Hellenismo". 
Y es la idea que subrayan también estas imágenes. Los arqueólogos europeos como Sir Austen Henry Layard en Nínive descubren, organizan y salvan antigüedades sepultadas en la tierra. Los locales siguen sus órdenes de manera disciplinada y obediente. Ellos únicamente se asombran incrédulos cada vez que una estatua aparece. Sólo piensan que Layard casi tiene poderes mágicos para leer inscripciones y saber dónde encontrar vestigios. Los locales sólo conciben las ruinas para un uso inmediato y destructivo. Un sarcófago sirve para lavar los platos. Esta es la imagen que nos transmiten. La otra parte de realidad nunca se muestra. El discurso de los locales, su vinculación con las ruinas, la historia de saqueos y destrucciones protagonizados o auspiciados desde Occidente es, sin embargo, un aspecto que no se menciona nunca (Momigliano, 1950; Hamilakis, 2011; Schnapp, et al., 2013; Anderson y Rojas, 2017).

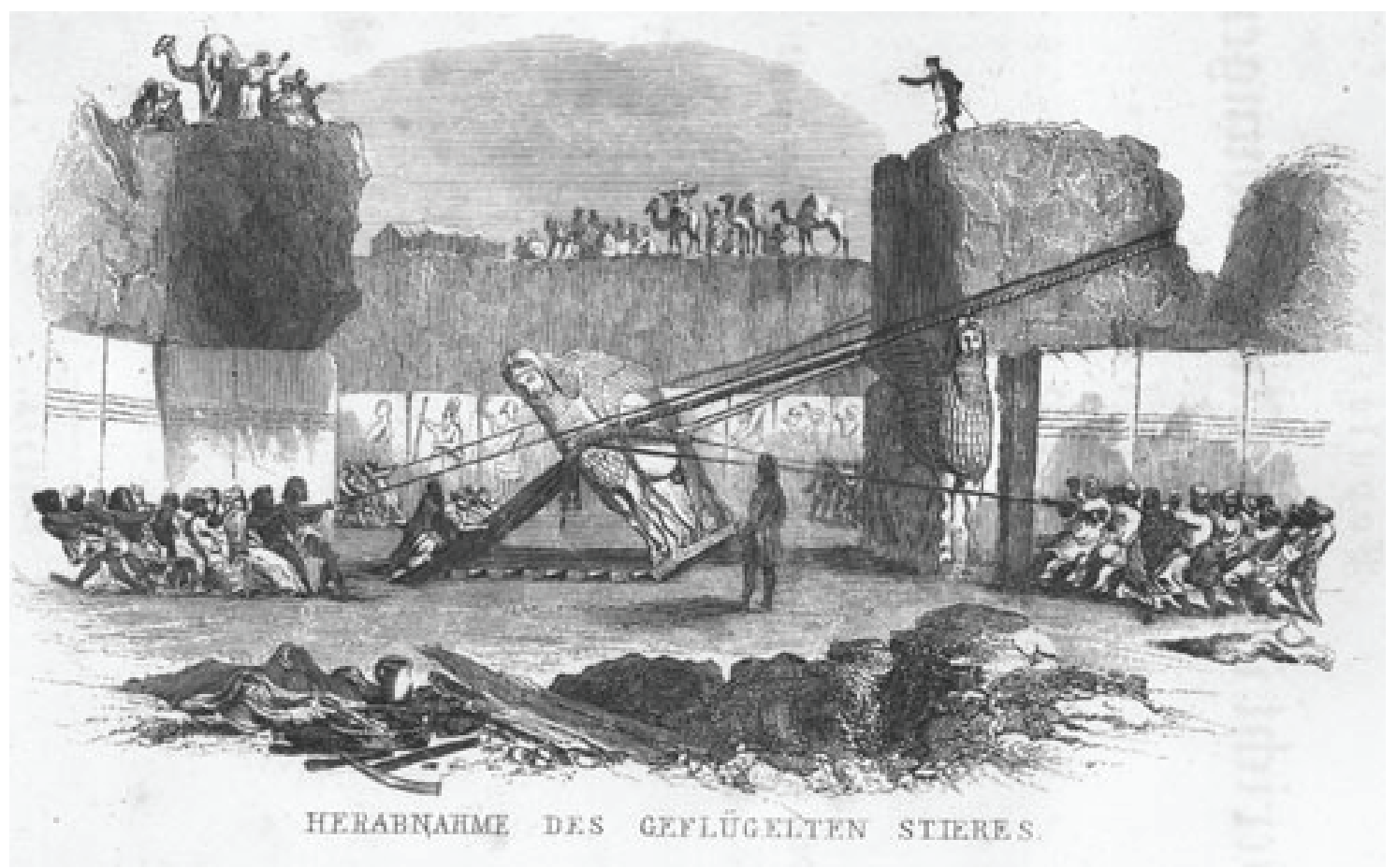

Fig. 1: Grabado de las excavaciones de Sir Austen Henry Layard en Nínive y Nimrud y del hallazgo de los famosos lamassu o toros alados con cabeza de hombre, hoy en el Museo Británico en Londres. Sir Austen Henry Layard, Nineveh and its remains, London, 1849, vol. 1, frontispiece.

A partir de entonces mi intención fue descubrir hasta qué punto este paradigma era cierto o no. Quería ver qué es lo que decían verdaderamente las fuentes árabes y el registro material. Encontré cosas realmente interesantes y comprobé que la realidad es mucho más compleja de lo que había pensado. Descubrí que en el siglo IX en Bagdad tuvo lugar un proceso de traducción de obras griegas muy importante. Esto era algo conocido en Occidente. Durante 
siglos los autores se han interesado por este proceso. De hecho es el único aspecto en el que aludían al mundo islámico para decir que gracias a ello cientos de obras se habían salvado y habían podido ser traducidas posteriormente al latín. Su labor habría sido la de salvaguardar un legado clásico que los europeos siempre han considerado propio, pero que los autores árabes habrían sido incapaces de valorar y aprovechar. Es la misma idea de antes. Sin embargo, en los textos árabes encontré una versión de la historia muy distinta: afirmaban que los musulmanes eran los verdaderos herederos y protectores del legado griego y que los bizantinos lo habían destruido y corrompido. Afirmaban incluso que la ciencia griega no era griega en realidad, sino persa, y que había sido Alejandro Magno el que, al conquistar su imperio, había ordenado traducir estas obras y quemar las bibliotecas persas, apropiándose de este legado (Rosenthal, 1975; Sabra, 1987; Gutas, 1998).

Comprobar la existencia de un discurso de apropiación tan similar en diferentes momentos y contextos me ayudó a comprender la complejidad de los procesos de recepción y ver la necesidad de su estudio. La profesora Gloria Mora Rodríguez se mostró entusiasmada de guiarme, así como el Dr. Eduardo Manzano Moreno (CSIC). Comencé así a desarrollar mi tesis doctoral y escogí entonces una región y un periodo histórico: al-Andalus en época omeya constituía un caso muy interesante, y no sólo por proximidad. Es el momento inmediatamente posterior al fin del mundo antiguo y el inicio de la formación de un estado islámico, en el que el urbanismo y la cultura de la antigua Hispania romana y visigoda siguen presentes, donde existe una cultura latina que es desconocida en el resto del mundo islámico influido por el griego, y donde además se dan una serie de condicionantes como son la existencia de una frontera frente al mundo cristiano, de una dinastía distinta a la que gobernaba el resto del mundo musulmán, y de un momento de esplendor político y cultural en el siglo X, el Califato de Córdoba (Acién Almansa, 1994 y 2000; Chalmeta, 1994; Manzano, 2006).

Pero además de todas estas características propias, hay tres rasgos fundamentales que hacen de al-Andalus un escenario único para nosotros.

El primero de estos aspectos es que, mientras que en Oriente se empleó material reutilizado de manera muy puntual entre los siglos VIII y X, en al-Andalus se recurrió a gran cantidad de piezas durante época emiral y califal. Los ejemplos se encuentran repartidos a lo largo de toda la Península Ibérica: los sillares y pilastras reutilizados en la alcazaba y el aljibe de Mérida, las estelas empotradas en las murallas de la fortaleza de Gormáz (Soria) o las piezas visigodas colocadas en el puente y la Puerta de Alcántara en Toledo son algunos casos, pero sin duda hay dos ejemplos que resultan muy significativos (Finster, 2009; Peña 2010). 
La mezquita de Córdoba es el primero al que hago mención. Se trata del edificio que más material reutilizado empleó en el siglo VIII en todo el Mediterráneo, más incluso que las mezquitas contruidas en Jerusalén o Damasco por los propios califas omeyas y más cantidad también que en las mezquitas de Samarra o Bagdad, erigidas por los Abbasíes. En el primitivo oratorio de Córdoba construido por Abd al-Raḥmān I en 170/786-7 se contabilizan un total de 680 piezas reutilizadas entre fustes (generalmente lisos pero también acanalados, con contracanales y helicoidales), capiteles (corintios o pseudo-corintios en su mayoría, pero también jónicos, la mayoría de época julio-claudia), cimacios y basas, de las que 360 serían romanas, a las que habría que añadir otras 40 basas bajo el pavimento actual, 90 cimacios lisos y 190 piezas tardoantiguas o visigodas. Sin embargo, las reformas emprendidas por Abd al-Rahmmān III (circunscritas al alminar de la mezquita) y las nuevas ampliaciones llevadas a cabo por al-Hakam II y Almanzor no hacían uso de piezas reutilizadas, sino de columnas y capiteles tallados ex novo. La única excepción son las cuatro columnas del miḥrāb de la ampliación de al-Hakam II, trasladadas desde el construido por 'Abd al-Raḥmān II, y algunas columnas emplazadas en la ampliación de Almanzor, desplazadas en realidad en el siglo XVI (Ewert and Wisshak, 1981; Cressier, 1984-1985; Peña, 2010).

Junto con la mezquita de Córdoba, otro ejemplo extraordinario de reutilización de antigüedades lo constituye la ciudad palatina de Madinat al-Zahrā', que 'Abd al-Raḥmān III ordenó construir a las afueras de Córdoba, junto a la sierra. A diferencia de la mezquita, este conjunto de piezas fue reunido y utilizado en época califal y no emiral, y además, no se trata de materiales constructivos más o menos apreciados, como columnas o capiteles, sino de un destacado conjunto de sarcófagos lisos y figurados y varias estatuas. Nada similar encontramos en el resto del mundo islámico durante el siglo X. La cifra de sarcófagos alcanza actualmente los veinticinco, de los cuales los sarcófagos figurados, datados entre mediados y segundo cuarto del siglo III d.C., ocupan por sus dimensiones y calidad un primer plano y son piezas excepcionales en el contexto hispánico. En cambio, el conjunto de estatuas es más reducido, pero no menos importante: un busto al que le falta el retrato fue encontrado en el patio anexo a la Dār al-ŷund, un herma que representa a Hércules-niño le falta la cabeza y la cabeza de un retrato femenino datado en el siglo III y procedente de la explanada frontera al Pórtico. En definitiva, un conjunto de antigüedades que constituye uno de los mejores casos de estudio de reutilización en al-Andalus y en el mundo islámico y el mejor ejemplo del interés «anticuario» de la dinastía Omeya durante el siglo X (Beltrán Fortes, 1989-1990; Beltrán Fortes et al., 2006; Vallejo Triano 2010; Calvo Capilla, 2014). 


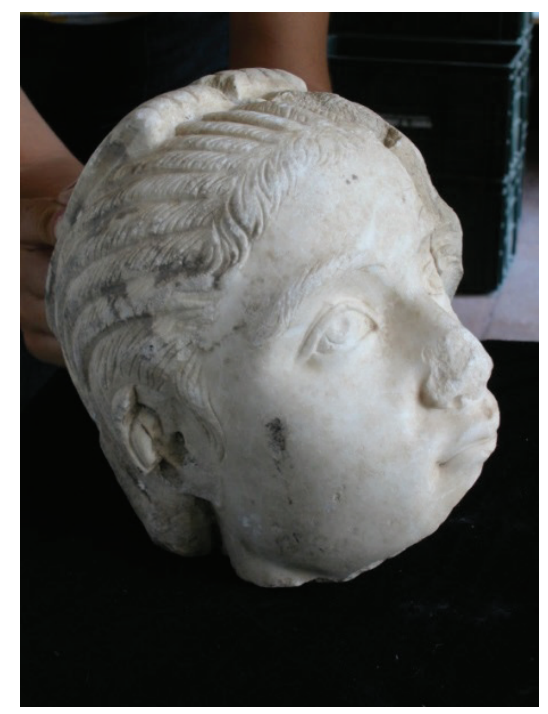

Fig. 2. Cabeza femenina del siglo III d. C procedente de la explanada frontera al Pórtico en Madinnat al-Zahră'. Imagen cortesía de Conjunto Arqueológico Madīnat al-Zahrā' /Junta de Andalucía.

El segundo de estos aspectos que hace singular a al-Andalus es el interés temprano y llamativo que parece haber suscitado la antigüedad. Las noticias árabes señalan que el emir 'Abd al-Rahmān II inquiría en todas las comarcas de al-Andalus en busca de columnas e instrumentos de toda clase, reuniéndolos y «llevándolos a la residencia califal de Córdoba», y afirman también que fue él el primero que introdujo en al-Andalus los libros y las ciencias de los antiguos, de los que había ordenado buscar traducciones en Bagdad y traerlas a Córdoba (Ibn Hayyān, Muqtabis II-I, trad. de Makkī y Corriente, 2001, f. 139v y 143v). El apreció e interés por la antigüedad abarca pues todos los aspectos. Por ejemplo, Al-Hakam II, reconocido por su inclinación a la sabiduría y sus gustos bibliófilos, habría ordenado buscar obras y traducciones de los sabios greco-latinos, reuniendo una biblioteca que se cifra en los 400.000 ejemplares, un número exagerado, sin duda, pero aun así sería ciertamente notable. En sus estanterías debían de encontrarse diversas obras que los autores árabes nos mencionan que llegaron a al-Andalus. Por ejemplo, un original en griego del De Materia Medica de Dioscórides y el Libro de las Causas de Pseudo-Apolonio de Tiana, ambos enviados por el emperador bizantino de Constantinopla como regalo para el príncipe. Y fruto también de los contactos diplomáticos, en este caso con el conde catalán Suñer, llegó hasta las manos del príncipe al-Hakam el Libro de los reyes francos, otra obra histórica acerca de los reyes merovingios y carolingios (Wasserstein, 1990-1991-1993; Signes, 1996, 184; Barceló i Roca, 1979).

E igualmente, las noticias referidas a las ruinas de al-Andalus están llenas de referencias extraordinarias. Una de las más relevantes alude al hallazgo de una fabulosa inscripción en Mérida. La noticia se remonta en última instancia 
a Aḥmad al-Rāzī y aparece inserta dentro de una conversación que gira en torno al mármol y las antigüedades que existían en Mérida desarrollada entre 'Umar, uno de los hijos del emir al-Hakam I, y al-'Āṣī b. 'Abd Allāh b. Ta'laba, general de 'Abd al-Raḥmān II y gobernador y constructor de la alcazaba emeritense. Precisamente este último señalaba:

«Me he quedado prendado de la calidad de sus mármoles (ruḥām). Cuando fui gobernador de Mérida, siempre que encontraba algún tipo de mármol que me gustaba, pedía que me lo trajeran. Un día, paseando por la ciudad, me fijé en una lápida de mármol labrada de la muralla ( $l \bar{u} j f i \bar{s}$ urha), en el momento en el que caía sobre ella abundante agua, parecía, a simple vista, estar viendo una auténtica joya [...] ordené que la sacasen de la muralla y, al extraerla, se descubrió un grabado en lengua cristiana (kutub al-'ayam). Reuní a los cristianos que se encontraban en Mérida para traducirlo [...] y uno de ellos me aseguró que sólo podía hacerlo un cristiano, porque fue compuesto en dicha lengua. Envié un mensajero expresamente para traerlo y me encontré con un clérigo viejo y decrépito, que cuando sostuvo dicha lápida ( $l \bar{u} j)$ entre sus manos, se le empañaron los ojos de lágrimas, mientras me decía: 'Lo que hay recogido en este grabado es un documento de la gente de $\bar{l} i y \bar{a}$, que construyó la muralla dándole una altura de quince codos'» (Al-Rušāṭī, Iqtibās, p. 54-5 y texto árabe y trad. en Torres Calzada (2014): 255-6 y 243-4).

Son varios los aspectos que quedan reflejados en esta noticia: la consideración especial que suscitaban las inscripciones, el aprecio por el mármol, la evidencia del expolio de materiales o la pervivencia del latín y la supuesta habilidad de un anciano para descifrar la inscripción. Me interesa ahora destacar que la noticia está marcada por distintos topoi (por ejemplo, el hallazgo de un objeto maravilloso o la figura de un sabio o anciano que desvela un conocimiento ancestral y revelador), sin embargo, la noticia se incluye dentro de un contexto verosímil como es el ambicioso proyecto de transformación de la ciudad que supuso la construcción de la alcazaba y el desmantelamiento parcial de la muralla de Mérida ordenado por 'Abd al-Raḥmān II como castigo a la rebeldía de la ciudad. De hecho, puede tratarse de un verdadero epígrafe, acaso el mismo que se documentó reutilizado en la alcazaba emeritense como imposta del arco de ingreso a la alcazaba y que fue recortado para encajar en ese lugar. En él se alude a la dedicación de una iglesia a Santa María bajo la advocación de Sancta Ierusalem, Īliyā o Jerusalén según los árabes (Navascués y de Juan, 1948: 309-310 y 354).

Finalmente, el tercer aspecto que hace de al-Andalus un escenario único son las fuentes árabes andalusíes. Tradicionalmente las fuentes árabes referidas al 
pasado no han sido consideradas en absoluto más que como elementos fantásticos cuya información y utilidad histórica y científica resultaba cuanto menos cuestionable. Sin embargo, las fuentes árabes muestran un conocimiento detallado de las fuentes clásicas, incluyen episodios y detalles históricos con gran fiabilidad e incluso incorporan nuevas informaciones a la luz de los hallazgos arqueológicos que tenían lugar entonces y que podían complementar su relato.

Especial atención merecen dos obras: la traducción árabe de las Historias de Orosio, el Kitab Hurusiyus y el relato sobre el pasado preislámico escrito por el historiador cordobés Aḥmad al-Rāzī (m. 344/955). Ambas obras recurren a fuentes clásicas para narrar diversos episodios de la historia universal y peninsular y aluden a Hércules, Viriato, Julio César, Augusto, Constantino o Leovigildo. No existe nada parecido a esto en el resto del mundo islámico medieval. En especial la obra de Aḥmad al-Rāzī, por su concepción de la Península como sujeto histórico, es algo realmente llamativo y solo sería comparable al proyecto historiográfico de Alfonso X que se llevó a cabo tres siglos después (De Gayangos, 1850: 5-10; Levi della Vida, 1954; Crónica de Moro Rasis, 1975; Sánchez-Albornoz, 1967: 267-375 y 1978; Molina, 1982-3 y 1984; Penelas, 2001).

Mi tesis se centró pues en realizar un estudio de las fuentes árabes y las evidencias materiales que pusiera de manifiesto cuáles son las pautas y procesos de recepción de la antigüedad en al-Andalus durante época omeya (92/711422/1031). Analicé las fuentes árabes relativas al pasado preislámico peninsular, a los monumentos antiguos que eran visibles todavía y a las referencias que dedican los autores a las ciencias y las obras de los autores greco-latinos y señalé qué y por qué se destruyó del pasado en al-Andalus y qué interesó conservar y por qué. Dos conclusiones resultan, a mi parecer, especialmente significativas.

\section{La reinterpretación de las estatuas clásicas: de ídolos paganos a talismanes}

Las noticias referentes a estatuas constituyen uno de los aspectos más llamativos de las fuentes árabes y de las evidencias atestiguadas por la arqueología. Su reutilización obedece a criterios prácticos y estéticos como en otros casos. Por ejemplo, la localización de estas imágenes figuradas en una ubicación particular, las puertas y murallas de las ciudades andalusíes, podría tener una mera razón práctica: muchos de los cementerios se encuentran a las afueras de las ciudades y sería fácil emplazarlas en las puertas como material de acarreo (Greenhalgh, 2009: 221). Sin embargo, cabe considerar también otros criterios. Por un lado, las puertas y murallas de las ciudades constituyen un símbolo de la misma y, por tanto, estas piezas fueron consideradas como símbolos de la ciudad, como muestra de su poder militar y riqueza. Por otro lado, las fuentes árabes indican que estas estatuas e imágenes eran consideradas talismanes y 
tenían propiedades mágicas, en conexión con la astrología, empleando en casos concretos el término talismán (țilasm).

Todo ello constituye un aspecto enormemente interesante puesto que esta singular reinterpretación de las estatuas preislámicas sirve justamente para vencer las reticencias que pudieran inspirar unas imágenes vinculadas siempre con la ŷāhiliyya y el paganismo, integrándolas en el presente andalusí, reinterpretándolas y otorgándoles una función determinada. De hecho, se podría aducir que las destrucciones y mutilaciones de imágenes a las que antes aludíamos tienen en realidad la intención de "neutralizar" estas estatuas y quitarles justamente su componente mágico (Flood, 2002, 648 y 2006).

La reinterpretación mágica de estas estatuas es un fenómeno bien conocido y documentado ya en la tardoantigüedad y en otras regiones del Mediterráneo. En realidad, la conexión con el antiguo paganismo es quizás el aspecto más llamativo de esta reinterpretación islámica de las estatuas clásicas. El origen de la misma parece estar vinculado justamente a las comunidades helenizadas de los sabeos de Harran, donde la conexión con las tradiciones herméticas y astrológicas parecen estar en la base de estas ideas (Pingree, 2002). De hecho, la conexión entre los talismanes y la astrología aparece una y otra vez en las fuentes andalusíes, de tal manera que, se puede apuntar a una posible relación entre estas noticias y el desarrollo de las ciencias de los astros en al-Andalus ya en la segunda mitad del siglo X, cuando aparecen obras que ahondan justamente en esta conexión entre astrología y magia talismánica.

Las estatuas e imágenes talismánicas quedan definidas por varios aspectos o características que se nos consignan en las noticias: una localización determinada y precisa, frecuentemente se alude a un origen preislámico y sustentan su eficacia en la analogía, es decir, adoptan la imagen de aquello sobre lo que ejercen su poder. Están realizadas en piedra, mármol, bronce, oro u otro metal precioso y basan su poder en una correspondencia o influencia con entes superiores que por lo general se refieren a un planeta o figura celeste. Gracias a ello protegen una ciudad, una región o incluso un país frente a cualquier tipo de amenaza (ataques enemigos, invasiones o plagas y enfermedades), pero si son alterados de alguna manera, el encantamiento de disuelve y el talismán deja de ser efectivo (Flood, 2006).

\section{El relato de la historia preislámica: un discurso de legitimación}

La segunda conclusión a destacar se refiere precisamente a la singularidad que presenta el relato de la historia preislámica elaborado por los autores árabes en el siglo X. En este momento existió un interés por conocer y elaborar un relato de los reyes y pueblos que dominaron la Península Ibérica antes de la llegada de los musulmanes. 
Esta narración, atribuible a Aḥmad al-Rāzī, se construye a partir de las fuentes clásicas, a las que sigue en muchas ocasiones de manera fidedigna y detallada. Sin embargo, cabe detectar también una continua reelaboración de estos relatos. Por ejemplo, el propio Aḥmad al-Rāzī complementa el relato del Kitāb Hurūšiyūs con otras fuentes como la crónica de San Jerónimo o la de Juan de Bíclaro, mientras que en la segunda mitad del siglo $X$ otros autores están también recogiendo el relato del historiador cordobés.

En cualquier caso, los autores andalusíes no se limitaron simplemente a copiar o traducir estas noticias, ya sea con aciertos o con errores, sino que elaboraron una narración nueva y original, incorporando tradiciones orientales, por ejemplo, aquellas que aluden al origen oriental de los išbān, un pueblo que habría conquistado la Península, habría fundado varias ciudades y también habría dado nombre a Hispania o Išbāniya, para complementar la versión clásica, sustentada en los autores latinos, que aludía a Išbān como un mítico rey antiguo (San Isidoro, Etimologías, XIV, IV, 28 e Ibn Habīb, K. Ta'rij $\left., 138, \mathrm{n}^{\mathrm{o}} 397\right)$.

Igualmente los autores árabes incluyeron tradiciones locales o autóctonas como por ejemplo la relativa al origen de la Era Hispánica (38 a. C), un sistema de datación antiguo empleado en la Península, conocido por los autores árabes como Era de Bronce ( $T a^{\prime} r \bar{r} j$ aș-șufr) puesto que su origen estaría en la pavimentación con placas de bronce del cauce del río Tíber en Roma, gracias a la recaudación de un impuesto en este metal en el cuarto año de reinado de Octavio Augusto (San Isidoro, Etimologías, V, 36, 4; K. Hurūšìūs, 335 no 9; Levi della Vida, 1943).

Por último, los autores árabes mencionaron también todo tipo de referencias procedentes de los hallazgos arqueológicos que tuvieron lugar en aquellos momentos, así como de la visión y estudio de las ruinas antiguas. Por ejemplo, los autores mencionan varios objetos hallados durante la conquista islámica en ciudades como Toledo y Mérida, a los que atribuyen un origen preislámico y oriental, como la Mesa de Salomón y que parecen corresponder al botín saqueado por los conquistadores en las iglesias hispanas. Así mismo incluyen referencias a estatuas halladas al excavar la tierra, por ejemplo en Itálica, y al hallazgo de inscripciones, como la de Mérida, o como la localizada en una iglesia cercana a Guadix, en la que la aparición del nombre de Recaredo sirvió a los autores árabes para relacionar su construcción con el rey visigodo y mencionar el dato al relatar su reinado (Ibn Habīb, Ta'rīj, 140; Al-Bakrī, K. al-masālik, 1517 y 1522; Hernández Juberías, 1996: 194-208).

A la vista de estas características, da la impresión que los autores árabes intentaron crear un relato que resultase lo más completo, verosímil y aceptable posible. Ello evidencia que en al-Andalus en el siglo X existió un interés por la 
antigüedad que iba más allá de la mera curiosidad o entretenimiento, sino que buscaba ofrecer un relato único sobre los hechos del pasado, que reelaboraba la memoria colectiva de Hispania y sentaba las bases de una nueva identidad local. Pero además, el relato histórico que trazan los autores, especialmente aquel que cabe atribuir a Ahmad al-Razi, es un discurso de legitimación.

En concreto, es una narración alternativa a la que presentaban las crónicas asturianas, redactadas a finales del siglo IX en el reino Asturiano y bajo el patrocinio de Alfonso III. Con ellas se pretendía consolidar la ideología de la reconquista, asegurando que los monarcas astures eran descendientes de los reyes visigodos y estaban pues legitimados para gobernar sobre toda la Península. El relato de Ahmad al-Razi es pues la respuesta a este otro discurso. Sin embargo, mientras que las crónicas asturianas solo incluyen una breve descripción de los emperadores romanos y de los reyes visigodos, la obra del cronista cordobés es mucho más ambiciosa, mencionando más detalles, incluyendo episodios y personajes, como las referencias a Hércules o a la historia prerromana, que no se encuentran en las crónicas del reino astur, y difiriendo en algunos puntos con el relato que éstas ofrecían, especialmente en lo referente al papel desempeñado por los últimos reyes visigodos, Witiza y Rodrigo. Todo ello buscaba no solo ofrecer una explicación satisfactoria acerca del origen de las ciudades y ruinas de al-Andalus, sino también contribuir a labrar una nueva legitimidad para el recién fundado Califato de Córdoba (Gil Fernández, Moralejo y Ruiz de la Peña, 1986).

\section{Conclusiones}

La obra de Aḥmad al-Rāzī supone un hito dentro de la historiografía árabo-islámica medieval e hispano-medieval. La ambiciosa perspectiva global que plantea el relato, tomando a la Península Ibérica como protagonista y trazando una narración completa de la historia preislámica resulta enormemente singular y poderosa. El sentido de su redacción debe buscarse en el contexto político andalusí de la primera mitad del siglo $X$, al igual que ocurre con el Kitāb Hurūšsiyus, y en la necesidad de construir una legitimación política que respondiera a los nuevos problemas y desafíos que rodean la instauración del Califato de Córdoba, trazando una comparativa entre pasado y presente. Su propósito no sería otro que el de rescatar del pasado una visión particular que sirviera para explicar y justificar ese presente y la realidad visible esos momentos. Tiene por tanto un propósito claramente pragmático, pero también político o ideológico que debe relacionarse con el círculo omeya del que el historiador cordobés fue un colaborador cercano. En definitiva, el pasado se construyó en al-Andalus de forma paralela a la progresiva arabización e implantación de un estado islámico centralizado y fue herramienta fundamental, 
de la que se usa y abusa, para reelaborar antiguas memorias y lealtades, y transformarlas en una única visión de los hechos, capaz de englobar discursos alternativos e identidades distintas.

\section{Fuentes}

Al-Bakrī. Kitāb al-Masālik wa-l-mamāik. Edição, Van Leeuwen, A. P./Ferré, A. 2 vols. Túnez: Servicio de Publicaciones, 1992.

Crónica del Moro Rasis. Edição, Catalán, D./De Andrés, Mª S. Madrid: 1975.

Crónicas asturianas. Edição, Gil, J./Moralejo, J. L./Ruiz de la Peña, J. I. Oviedo: Servicio de Publicaciones, 1986.

Ibn Ḥabīb. Kitāb al-ta'rīj. Edição, Aguadé, J. Madrid: Publicaciones CSIC, 1991.

Ibn Hayyān. Muqtabis II-I. Crónica de los emires Alhakam I y Abdarrahman II entre los años 796 y 847. Tradução, Makkī, M. A./Corriente, F. Zaragoza: 2001.

Isidoro de Sevilha. Etimologías (Etymologiae). Edição e tradução, Oroz Reta J. e Marcos Casquero. 2 vols. Madrid: Biblioteca de Autores Cristianos, 1982.

Kitāb Hurūšìūs. Kitāb Hurūšìūs: traducción árabe de las "Historiae adversus paganos" de Orosio. Edição Penelas, M. Madrid: Publicaciones CSIC, 2001.

Al-Rušătị. Andalus en el Kitāb iqtibās al-anwār y en el Ijtiṣār iqtibās al-anwār. Edição Molina López, E./Bosch-Vilá, J. Madrid, 1990.

\section{Referencias bibliográficas}

ACIÉN ALMANSA, M. Entre el feudalismo y el islam. Úmar ibn Hafșun en los investigadores, en las fuentes y en la historia. Jaén: Servicio de Publicaciones, 1994.

- La herencia del protofeudalismo visigodo frente a la imposición del estado islámico. In: CABALLERO, L. e MATEOS, P. (eds.). Visigodos y omeyas: un debate entre la Antigüedad tardía y la Alta Edad Media. Madrid: Publicaciones CSIC, 2000.

ANDERSON, B. e ROJAS, F. (eds.). Antiquarianisms: contact, conflict, comparison. Oxford: Oxbow Books, 2017.

BARCELÓ, M. Una nota entorn del «Llibre dels reis francs» regalat pel bisbe Gotmar de Girona, l' any 380-940, a Al-halkam, a Còrdova. Annals de l'Institut d'Estudis Gironins. Girona: 25, 1, 1979, pp. 127-136. 
BELTRÁN, J. La colección arqueológica de época romana aparecida en Madinat al-Zahra. Cuadernos de Madinat al-Zahra. Córdoba: 2, 1988-90, pp. 109-126.

BELTRÁN FORTES, J. et al. Los sarcófagos romanos de Andalucia. Murcia: Servicio de Publicaciones, 2006.

CALVO, S. The reuse of classical antiquity in the palace of Madinat al-Zahra and its role in the construction of caliphal legitimacy. Muqarnas. Nova York: 31, 1, 2014, pp. 1-33.

CHALMETA, P. Invasión e islamización. La sumisión de Hispania y la formación de al-Andalus. Madrid: Maphre, 1994.

CRESSIER, P. Les chapiteaux de la grande Mosquée de Cordoue (oratoires d' 'Abd al-Rahman I et d' 'Abdar-Rahman II) et la scuplture de chapiteaux à l'époque émirale. Première partie. Madrider Mitteilungen. Frankfurt: 25, 1984, pp. 216-281 e 26, 1985, pp. 257-313.

DE GAYANGOS, P. Memoria sobre la autenticidad de la Crónica denominada del moro Rasis. Memorias de la Real Academia de la Historia. Madrid: 8, 1850, pp. 21-100.

DÍAZ-ANDREU, M. A world history of nineteenth-century archaeology: nationalism, colonialism, and the past. Oxford: Oxford University Press, 2007.

EWERT, C. e WISSHAK, J.-P. Forschungen zur almohadischen Moschee I. Vorstufen: Hierachische Gliederungen westislamischer Betsäle des 8. bis 11. Jahrhunderts: Die Hauptmoscheen von Qairawan und Córdoba und ihr Bannkreis, Mainz: 1981.

FINSTER, B. Die Werwendung von Spolien in umayyadischer Zeit. In: SCHATTNER, T. G. e Valdés, F. (Eds.). Spolien im Umkreis der Macht / Spolia en el entorno del poder. Actas del coloquio en Toledo del 21 al 22 de Septiembre de 2006. Mainz, 2009.

FLOOD, F. B. Between cult and culture: Bamiyan, Islamic iconoclasm, and the Museum. The Art Bulletin. Nova York: 84, 4, 2002, pp. 641-659.

- Image against nature: Spolia as apotropaia in Byzantium and the dar al Islam. The Medieval History Journal. Londres: 9, 1, 2006, pp. 143-166.

GREENHALGH, M. Marble past, monumental present. Building with antiquities in the mediaeval Mediterranean. Leiden/Boston: Brill, 2009.

GRESS, D. From Plato to NATO: The idea of the West and its opponents. New York: Free Press, 1998. 
HAMILAKIS, Y. Indigenous archaeologies in Ottoman Greece. In: BAHRANI, Z., ÇELIK, Z., e ELDEM, E. (eds.). Scramble for the past: a story of archaeology in the Ottoman Empire, 1753-1914. Istambul: Salt, 2011.

HERNÁNDEZ, J. La península imaginaria: mitos y leyendas sobre al-Andalus. Madrid: Publicaciones CSIC, 1996.

LEVI DELLA VIDA, G. The Bronze Era in Moslem Spain", Journal of the American Oriental Society. Pensilvânia: 63, 3, 1943, pp. 183-191.

- La traduzione araba delle Storie di Orosio. Al-Andalus. Madrid: 19, 1954, pp. 257-293.

MANZANO, E. Conquistadores, emires y califas. Los omeyas y la formación de al-Andalus. Barcelona: Crítica, 2006.

MOLINA, L. Sobre la procedencia de la Historia preislámica inserta en la Crónica del moro Rasis. Awraq. Madrid: 5-6, 1982-3, pp. 133-139.

- Orosio y los geógrafos hispanomusulmanes. Al-Qantara. Madrid: 5, 1984, pp. 63-92.

MOMIGLIANO, A. Ancient history and the antiquarian. Journal of the Warburg and Courtauld Institutes. Londres: 13, 3-4, 1950, pp. 285-315.

NAVASCUÉS, J. Ma. La dedicación a la iglesia de Santa María y de todas las vírgenes de Mérida. Archivo Español de Arqueología. Madrid: 21, 73, 1948, pp. 309-350.

PEÑA, A. Estudio de la decoración arquitectónica romana y análisis del reaprovechamiento de material en la Mezquita Aljama de Córdoba: Córdoba: Servicios de Publicaciones, 2010.

PINGREE, D. The Sabians of Harran and the classical tradition. International Journal of the Classical Tradition. Londres: 9, 2002, pp. 8-35.

ROSENTHAL, F. The classical heritage in Islam. London: Routledge \& Kegan Paul, 1975.

SÁNCHEZ-ALBORNOZ, C. Investigaciones sobre historiografía hispana medieval. Buenos Aires: Editora Nacional, 1967

- Adiciones al estudio de la Crónica del moro Rasis. Madrid: Cátedra, 1978.

SCHNAPP, A. et al. World antiquarianism: comparative perspectives. Los Angeles: Getty Research Institute, 2013. 
SIGNES CODOÑER, J. La diplomacia del libro en Bizancio. Algunas reflexiones en torno a la posible entrega de libros griegos a los árabes en los siglos VIII-X, Scrittura e Civiltà. Roma: 20, 1996, pp. 153-187.

TIETZE LARSON, V. Classics and the acquisition and validation of power in Britain's 'Imperial Century' (1815-1914). International Journal of the Classical Tradition. Londres: 6, 1999/2000, pp. 185-225.

TORRES CALZADA, K. El emeritense: noticia de la ciudad de mérida recogida en el Iqtibās al-anwār de Abū Muhammad al-Rušățī (466/1074-542/1147). Miscelánea de Estudios Árabes y Hebraicos. Sección Árabe-Islam. Granada: 63, 2014, pp. 233-256.

VALLEJO, A. La ciudad califal de Madinat al-Zahra. Arqueología de su arquitectura. Córdoba, Almufara, 2010.

VALLVÉ, J. Fuentes latinas de los geógrafos árabes. Al-Andalus, 32, 1967, pp. 241-260.

WASSERSTEIN, D. J. The library of al-Hakam II al-Mustansir and the culture of Islamic Spain, Manuscripts of the Middle East. Londres: 5, 1990-1991-1993, pp. 99-105. 